\title{
Facts and ideas from anywhere
}

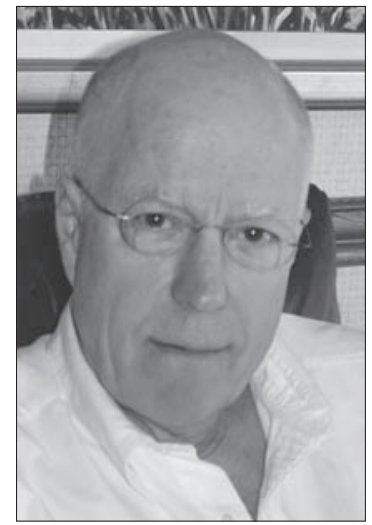

William C. Roberts, MD
IT'S THE CHOLESTEROL, STUPID!

During the 1992 presidential campaign in the USA, the Clinton campaign slogan was "It's the economy, stupid," and that phrase apparently was helpful in getting Mr. Clinton elected president. Several recent publications have been highly critical of some lipidlowering trials using statin drugs and also have debased the cholesterol "hypothesis" on atherosclerosis (1-3).

What is the evidence that "elevated cholesterol" causes atherosclerosis? There are four supporting arguments in my view (4-7). 1) Atherosclerotic plaques are easily produced experimentally in herbivores (e.g., rabbits, monkeys) simply by feeding these animals cholesterol (e.g., egg yokes) or saturated fats. Indeed, atherosclerosis is probably the second easiest disease to produce experimentally. (The first is an endocrine deficiency - simply excise an endocrine gland.) 2) Cholesterol is present in atherosclerotic plaques in experimentally produced atherosclerosis and in plaques in human beings. 3) Societies and individuals with high serum cholesterol levels (total and low-density lipoprotein [LDL] cholesterol) compared to populations and individuals with low levels have a high frequency of atherosclerotic events, a high frequency of dying from these events, and a large quantity (burden) of plaque in their arteries. (The best study in my view supporting this thesis is the Seven Countries study [8-10].) 4) Lowering total and LDL cholesterol levels decreases the frequency of atherosclerotic events, the chances of dying from these events, and the quantity of plaques in the arteries. No one has produced atherosclerosis experimentally by increasing the arterial blood pressure or glucose levels or by blowing smoke in the faces of rabbits their entire lifetime or by stressing these animals. The only way to produce atherosclerosis experimentally is by feeding high-cholesterol and/or high-saturated-fat diets to herbivores. (Atherosclerosis is not a disease of carnivores, and it is not possible to produce atherosclerosis in carnivores [dogs, cats, tigers, lions, etc.] unless the thyroid gland is removed or made dysfunctional before a high-cholesterol or high-saturatedfat diet is administered [11]).
Why has the proven causal relation between abnormal serum LDL cholesterol and atherosclerosis been so difficult to accept by so many extremely intelligent physicians? One factor, in my view, is that this cholesterol-atherosclerosis causal relation has been diluted by the concept of multiple atherosclerotic risk factors and the idea that atherosclerosis is a multifactorial disease. The Framingham study, which has taught us all so much, introduced the concept of "risk factors" and fostered the view that the greater the number of risk factors present, the greater the chance of atherosclerotic events (12). As a consequence, "elevated cholesterol" became just one of several risk factors and was perceived as essentially having no more influence than elevated systolic blood pressure, diabetes mellitus ("glucose intolerance"), cigarette smoking, abdominal obesity, lack of regular physical activity, family history, or left ventricular hypertrophy except in the younger patients (13). The view that atherosclerosis is a multifactorial disease has muddled the waters in my view. This is not to say that cigarette smoking, elevated blood pressure, diabetes mellitus, obesity, and inactivity are not harmful —of course they arebut if the serum LDL cholesterol is $<60 \mathrm{mg} / \mathrm{dL}$ or the serum total cholesterol is $<150 \mathrm{mg} / \mathrm{dL}$, there is no evidence (with extremely rare exceptions [14]) in my view that these other "risk factors" cause atherosclerosis.

A second factor is the introduction and propagation of the thesis that atherosclerosis is an inflammatory disease (15). Yes, a few mononuclear cells are regularly seen in experimentally produced atherosclerotic plaques but not commonly in plaques of patients with fatal coronary disease or in plaques excised by endarterectomy $(16,17)$. And, yes, some blood inflammatory markers are commonly elevated in persons with atherosclerotic events. But, many patients have atherosclerotic events when the high-sensitivity (hs) C-reactive protein (CRP) is normal $(<1 \mathrm{mg} / \mathrm{dL})$, and patients with the highest levels of hs-CRP (e.g., rheumatoid arthritis, systemic lupus erythematosus) have only a slightly higher frequency of atherosclerotic events than do others of similar age and sex with normal or near-normal hs-CRP levels. The same principle, however, does not apply to cholesterol. The patients with the highest serum levels of total and LDL cholesterol, namely those patients with homozygous familial hypercholesterolemia, have an incredibly high frequency of atherosclerotic events, and they have 
them at very young ages-teenage years (18). And patients with the next highest serum LDL cholesterol levels, namely those with heterozygous familial hypercholesterolemia, have atherosclerotic events often in their 30s and 40s.

A third factor preventing acceptance of the causal relation between abnormal serum LDL cholesterol and atherosclerosis has been the observation that among adults with nonfamilial hypercholesterolemia but similar levels of serum LDL cholesterol, some develop atherosclerotic events and others do not. It is in this group particularly in my view that the other "risk factors" as well as high-density lipoprotein (HDL) cholesterol levels come into play. Of two people of similar age and sex and similar serum LDL cholesterol levels, say $130 \mathrm{mg} / \mathrm{dL}$, the patient whose systolic systemic blood pressure is $170 \mathrm{~mm}$ $\mathrm{Hg}$ versus the other patient with a systolic pressure of $115 \mathrm{~mm} \mathrm{Hg}$ is at much greater risk of an atherosclerotic event. And cigarette smoking may work in a similar fashion. Nevertheless, if the serum LDL cholesterol is $<60 \mathrm{mg} / \mathrm{dL}$, maybe $<50 \mathrm{mg} / \mathrm{dL}$, irrespective of the degree of blood pressure elevation or the number of cigarettes smoked daily, atherosclerotic plaques do not develop.

Another factor may be the use of multiple atherosclerotic risk factors in the guidelines for whom to treat and whom not to treat with lipid-lowering drugs. Although the guidelines do focus on the serum LDL cholesterol level, the number of other "risk factors" present plays a prominent role in this therapeutic decision (19). If no other nonlipid risk factors are present or if only one non-LDL cholesterol risk factor is present and there have been no previous atherosclerotic events and diabetes mellitus is not present, the magical drug treatment number is an LDL cholesterol level $>190 \mathrm{mg} / \mathrm{dL}$. Refraining from drug intervention until this very high LDL cholesterol level is reached plays down or even nullifies the importance of cholesterol in preventing events. (It is important to realize that the lipid-lowering drug guidelines [1988, 1993, 2001, and 2004] have to do only with reducing atherosclerotic events. They do not concern themselves with preventing atherosclerotic plaques in the first place. Of course, if atherosclerotic plaques are prevented, atherosclerotic events do not occur!)

Such high guideline drug treatment levels keep, in my view, many persons deserving of lipid-lowering drug therapy from receiving these magical agents (20). The danger of high cholesterol levels to longevity was recognized by the life insurance companies in the 1930s but not by physicians. The normal range of serum total cholesterol in laboratory reports for decades was listed as 150 to $300 \mathrm{mg} / \mathrm{dL}$. In 1972, one of the world's most prominent lipidologists reported that his total cholesterol "worry level" for patients was a value $>300 \mathrm{mg} / \mathrm{dL}$. If the expert uses such high numbers, what importance can be placed on cholesterol by the nonexpert community? Incidentally, for the first several decades of the Framingham study, an "elevated cholesterol" was defined as a serum total cholesterol $>250 \mathrm{mg} / \mathrm{dL}$. At this level, it is easy to understand how this "risk factor" did not separate itself from the others.

It is time to move on from a goal "to decrease risk" to a goal "to prevent plaques" (21). To do so requires much lower levels of LDL cholesterol than advocated by the guideline publications. My goal for all individuals worldwide is a serum LDL cholesterol at least $<100 \mathrm{mg} / \mathrm{dL}$ and ideally $<60 \mathrm{mg} / \mathrm{dL}$. The beauty of the JUPITER trial is that it dramatically demonstrates what incredible reductions in events can be produced in a short period of time ( $<2$ years) by reducing the LDL cholesterol by $50 \%$ even when starting from a level considered by many to be normal $(<130 \mathrm{mg})$. The mean level $(108 \mathrm{mg} / \mathrm{dL})$ might be considered "good" or even "great" by many physicians, but lowering it to $55 \mathrm{mg} / \mathrm{dL}$ (by rosuvastatin $20 \mathrm{mg} / \mathrm{dL}$ ) decreased all events by $>40 \%$, indeed nearly $50 \%$, including a reduction in stroke by $48 \%$ ! This trial beautifully shows that we can drastically reduce or even prevent atherosclerotic events and expensive procedures by taking a single pill every day and do it safely. Most Americans will not reach the JUPITER treatment levels (LDL cholesterol $55 \mathrm{mg} / \mathrm{dL}$ ) by diet alone. The statin drugs have been ingested by humans now for nearly 30 years, and their safety and thus benefit/risk ratio may be the best of any proven useful medication. The toxicity resides mainly in atherosclerosis, not in the drug.

I consider it unfortunate that there continues to be so much criticism of statin drugs, which I consider to be the best cardiovascular drug ever created. ${ }^{*}$ These drugs can prevent first and subsequent atherosclerotic events, they can reduce cardiovascular and all-cause mortality rates, they have the capacity to reduce the quantity of atherosclerotic plaques already present, and by decreasing the frequency of myocardial infarcts they reduce the frequency of heart failure and malignant ventricular arrhythmias. Their ability to reduce the serum levels of CRP may have benefits not yet fully appreciated. The discoverer of the first statin drug (Akira Endo, PhD) is deserving of the Nobel Prize for medicine!

The lower the LDL cholesterol the better, and this principle has been established repeatedly despite the voices of the anticholesterol, antistatin fallacy mongers! It's the cholesterol, stupid!

\section{US LIPID LEVELS, 1996-2006}

Data from the second, third, and fourth National Health and Nutrition Examination Surveys (NHANES) (1976-1980, 1988-1994, and 1999-2006) were examined to assess trends in our serum lipid levels, lipid-lowering medication use, and body weight (22). During the 30-year period, the mean age fell from 50 to 45 years; the percentage with total cholesterol levels $\geq 240 \mathrm{mg} / \mathrm{dL}$ fell from $25 \%$ to $16 \%$ and those with levels $<200$ rose from $45 \%$ to $52 \%$; the percentage with LDL cholesterol levels $\geq 160$ fell from $20 \%$ to $12 \%$ and those with levels $<100$ rose from $17 \%$ to $31 \%$; the percentage with HDL cholesterol levels $<40$ was unchanged $(21 \%$ and $19 \%)$ and those with levels $\geq 60$ rose from $18 \%$ to $28 \%$; the percentage with triglyceride levels $\geq 200$ was unchanged (16\% and $18 \%$ )

*I have no investments in pharmaceutical or device companies, I receive no grants from them, and I am on no advisory boards of industry. I have, however, in the past given talks sponsored by pharmaceutical companies. This editorial was originally published in the American Journal of Cardiology (2010;106:1364-1366) and is reprinted with permission from Elsevier. 


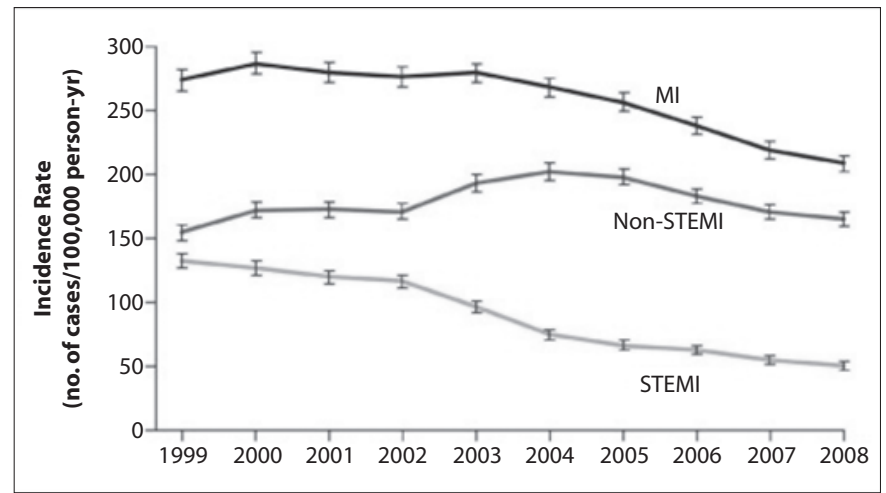

Figure. Age- and sex-adjusted incidence rates of acute myocardial infarction, 1999 to 2008. I bars represent 95\% confidence intervals. MI indicates myocardial infarction; STEMI, ST-segment elevation myocardial infarction. Reprinted with permission from Yeh RW et al., N Engl J Med (23). Copyright Massachusetts Medical Society.

and those with levels $<150 \mathrm{mg} / \mathrm{dL}$ also were unchanged $(67 \%$ and $67 \%$ ). The percentage of those who were obese (body mass index $\geq 30 \mathrm{~kg} / \mathrm{m}^{2}$ ) increased from $15 \%$ to $34 \%$. During the 30 years, the mean total cholesterol fell from 209 to 200; LDL cholesterol in men fell from 135 to 120 and in women from 132 to 117 ; HDL cholesterol in men was unchanged (45 and 47) and in women rose from 54 to 58; triglyceride levels in men rose from 153 to 161 and in women from 121 to $131 \mathrm{mg} / \mathrm{dL}$. Thus, this report provides both good and bad news. The lowering of total cholesterol and LDL cholesterol levels is obviously good, but the increased obesity and triglyceride levels are not good. The mean body mass index increased from 26 to $29 \mathrm{~kg} / \mathrm{m}^{2}$ during the 30 years.

\section{HEART ATTACKS DECREASING}

Yeh and colleagues (23) from several US medical centers identified 46,086 hospitalizations for myocardial infarction during 18,691,131 person-years of follow-up from 1999 to 2008. During the 9-year follow-up, the age- and sex-adjusted incidence of myocardial infarction decreased from 274 to 208 cases per 100,000 person-years, representing a $24 \%$ relative decrease over the 9-year study (Figure). During the period, the incidence of non-ST-elevation myocardial infarction actually increased, and the incidence of ST-elevation myocardial infarction dramatically decreased (from 133 to 50 cases per 100,000 person-years). Thirty-day mortality also decreased significantly during the 9-year period of study. This is good news, of course!

\section{STAYING WELL}

Gene Stone authored The Secrets of People Who Never Get Sick, which appeared in 2010 (24). The book tells the stories of 25 people who each possess a different secret of excellent health. The following are some "secrets" described in this superb book.

Luigi Cornaro. He was a wealthy Venetian nobleman born to a prosperous family around 1460. Like his peers in Renaissance Italy, Cornaro lived extravagantly, and that included eating whatever and whenever he wanted. He consumed four or five massive meals a day. In the 1490s, as he was approaching his 40th birthday, he fell ill. His doctors informed him that if he wanted to survive, he would have to moderate his diet. Cornaro designed himself a new diet, cutting back drastically on the quantity of food he consumed. Each day, he limited himself to 12 ounces of solid food and 14 ounces of wine (the water of the day). His plan worked almost immediately. His health improved so dramatically that he continued his plan until age 68 when his doctors worried that his food intake was too meager and insisted he eat and drink more generously. He complied but soon began feeling badly and promptly returned to his lighter menu, which he maintained for the rest of his life, until age 102. Cornaro wrote about his plan in his four-volume book, often translated as Discourses on a Temperate Life, in which he articulated his philosophy that people should eat less as they grow older. Cornaro not only lived a very long time but he remained healthy until just before his death. As he noted, "A long life full of disease and misery is worse than no life at all."

George Burns. His real name was Nathan Birnbaum. He picked up alias George Burns when he entered show business. One of 12 children, Burns started singing when he was a child, quitting school in the fourth grade to make it a profession. $\mathrm{He}$ was doing a solo vaudeville act—singing, dancing, and telling jokes-when he met Grace Ethel Cecile Rosalie Allen, a young Irish-Catholic singer. Soon afterwards, the two realized they worked better together than on their own and became Burns and Allen, one of the most famous comedy teams of the 20th century. Gracie died in 1964 at age 69, and Burns scaled back for a while but then became a major success in several movies. He once remarked, "I get a standing ovation just standing." Burns also was the author of 10 bestselling books. Even when Burns was approaching 90 he looked remarkably healthy. After lunch, he would play cards, take a nap, go about his day, and meet friends for dinner. He was asked by one of his friends when he was nearly 100, "How do you stay so fit and healthy? What is your advice?" Burns took a puff from his ever-present cigar, exhaled, and said in his gravelly voice, "Eat half."

No question: caloric reduction is a lifespan extender. Luigi Cornaro may have been the first person to write about eating less for better health. In the early 20th century, a Newburgh, New York, physician, William Jones, reported that a fasting spider will live longer than one that eats a normal diet. In the 1930s, studies at Cornell University showed that rats on a limited diet lived twice as long as other rats. Similar results were found in mice.

Thomas Edison stated:

I keep my health by dieting. People gorge themselves with rich foods, use up their time, ruin their digestion, and poison themselves. ... If the doctors would prescribe dieting instead of drugs, the ailments of normal man would disappear. Half the people are food drunk all the time. That is the secret of my health.

In his 1983 book, How to Live to Be a Hundred-or More, George Burns wrote on his supposed diet. Breakfast: one small glass of orange juice, a bowl of bran cereal with milk, and 
2 cups of black coffee. Lunch: a bowl of canned salmon with white vinegar and lemon, half an English muffin toasted, and one cup of black coffee. Dinner: a bowl of soup, a mixed green salad, broiled fish, 2 vegetables, one slice of bread, one cup of black coffee, and ice cream.

Stone's book went on to discuss cold showers, detoxification, eating dirt, the importance of friends, garlic, germ avoidance, herbal remedies, hydrogen peroxide, lifting weights, napping, positive attitude, probiotics, and several other topics.

I was particularly intrigued by Stone's comment on sleeping. According to research by sleep specialist Neil Stanley, MD, of the University of Surrey, UK, sharing a bed with a partner is not necessarily a healthy idea for either party. Between restless limbs, snoring, and disagreements over what time to set the alarm, couples suffered an average of $50 \%$ more sleep disturbances if they shared a bed than if they slept solo, according to one study. The tradition of sharing a marital bed is relatively new, dating from the Industrial Revolution, when population growth meant more people with less furniture. In ancient Rome, for example, the marital bed was used only for sex, not sleeping. Robert Meadows, $\mathrm{PhD}$, another researcher at the University of Surrey, demonstrated that when couples share a bed and one of them moves in his or her sleep, there is a $50 \%$ chance that the partner will be disturbed. Scientists appear to have concluded that if you are successfully sleeping with someone, fine; if not, there is no shame, and much to gain, in sleeping apart.

\section{ROAD ACCIDENTS AND TRAVELING ABROAD}

According to a USA Today analysis of the past $7 \frac{1}{2} 2$ years of State Department data, about 1800 Americans_almost a third of all Americans who died of nonnatural causes while abroad-were killed in road accidents in foreign countries from January 1, 2003, through June $2010(25,26)$. On average, one American traveler dies on a foreign road every 36 hours. Almost $40 \%$ of the deaths occurred in Mexico, followed by Thailand, the Dominican Republic, Germany, and Spain. The lethal cocktail of killer roads, unsafe vehicles, dangerous driving, and disoriented travelers is killing an estimated 25,000 travelers to foreign countries each year.

The number of tourist deaths is dwarfed by the total number of road fatalities worldwide. Nearly 1.3 million people die and up to 50 million people are injured each year, according to the World Health Organization estimates. About half of the fatalities are occupants of four-wheel motor vehicles; the other half are bicyclists, motorcyclists, and pedestrians. More than $90 \%$ of the world's road fatalities occur in lowincome and middle-income countries, which have nearly half of the world's registered vehicles. The fatality rates on their roads are nearly double those of high-income countries. Mexico is the most common foreign country visited by Americans, followed by Canada. A total of 682 American travelers died in Mexico from January 2003 through June 2010; Canada registered 31 road deaths of US citizens.

Why so many deaths in low- and middle-income countries? Many of these countries have roads that were designed poorly and lack safety features such as barriers. Many roads are shared by motorists, pedestrians, cyclists, and animal-drawn carts and lack safe zones for the more vulnerable road users. Many countries lack or fail to enforce laws for speeding, drunken driving, and other traffic hazards. Many also lack or fail to enforce laws for wearing seatbelts and motorcycle helmets and using child restraints. The most recent World Health Organization statistic shows that two middle-income countries, China and India, have the most road deaths. In 2007, nearly 221,000 people were killed in China and about 196,000 in India. Every 6 seconds someone is killed or injured on the world's roads.

For safety on foreign roads, travelers might consider the following: read foreign country road travel reports on the State Department's website, http://travelstate.gov. The Road Safety Overseas page links to many road-safety resources. Consider hiring a well-trained driver instead of driving a car in lowincome and some middle-income countries. Drive or ride in vehicles only with an accessible seatbelt. Learn how to use all controls and signals on a rental vehicle in the parking lot before getting on a road. Practice driving in a less populated area before driving in heavy traffic, especially if you are in a country where drivers drive on the left side of the road. Become familiar with the local road culture and road regulations. Learn about seasonal hazards and local holidays when road crashes are particularly high. Avoid night road travel in countries with poor safety records or mountainous terrain. Avoid lightweight minivans, motorcycles, scooters, and mopeds. If you travel on a motorcycle, scooter, or moped, wear a helmet that meets safety regulations. Pedestrians are at most risk, so be aware of local traffic patterns, cross roads only at crosswalks, and wear reflective clothing at night.

\section{MORE ON THE NATIONAL DEBT}

As of October 2010, the Obama administration has borrowed $\$ 3$ trillion according to the US Treasury Department (27). It took from 1776, when the USA became an independent country, until 1990, the year after the Berlin Wall fell, for the federal government to accumulate a total of $\$ 3$ trillion in debt. It took only from January 2009, the day President Barack Obama was inaugurated, until October 15, 2010, for the Obama administration to add $\$ 3$ trillion to the federal debt! The overall debt of the federal government, according to the Treasury Department, is now \$13.666 trillion. Each business day the Treasury Department's Bureau of the Public Debt publishes the exact amount, to the penny, of total federal debt as of the close of the previous business day. At the close of business on January 20, 2009, the total debt of the federal government was $\$ 10,626,877,048,912.08$. On October 15, 2010, the federal government borrowed an additional $\$ 58,15,979,549,154.06$, bringing the total federal debt at the close of business to $\$ 13,665,926,643,255.96$, an increase of $\$ 3,039,049,594,342.88$ since President Obama's inauguration.

\section{COSTS OF OBAMACARE}

Dr. Mark Siegel, an associate professor of medicine at New York University Langone Medical Center, discussed the 
new health care reform law in a piece in USA Today, October 2010 (28). According to Siegel, the new health care law mandates and extends the kind of insurance that breeds overuse, thereby driving up costs and premiums. The medical system is about to be overwhelmed because there are no disincentives for overuse. The new bill covers all Americans with preexisting conditions. That's not the issue, says Dr. Siegel. We are going to get into trouble because of the kinds of coverage that the new law mandates. There are no breaks on the system. Copays and deductibles will be kept low and preventive services will have no copays at all. Without at least a pause to consider necessity and/or costs, expect waiting times to increase, emergency rooms to be clogged, and lead times to be longer for appointments. Patients with new Medicaid who can't find a physician will go to emergency rooms. The escalating costs of these visits (both the necessary and unnecessary ones) will be transferred directly to the American public, both in the form of taxes as well as escalating insurance premiums.

Beginning in 2014, insurance exchanges will be set up in every state so that individuals can choose a health insurance plan. But don't expect to find individually tailored plans or those with higher deductibles or copays. They won't be there because they can't receive the government's stamp of approval. In the new system, patients can go to their physician as often as they like. But will they get the same level of care? Almost certainly no, says Dr. Siegel. He anticipates that expensive chemotherapy, coronary procedures, and organ transplants will have a tougher time being approved, as is already the case in Canada.

The new Independent Payment Advisory Board, established by the health reform law to "recommend proposals to limit Medicare spending growth," will advise Medicare that some treatments are more essential and more cost effective than others. These value judgments will reduce the options of practicing physicians, and private insurers will follow suit.

Although President Obama indicated that we would be able to keep our current insurance plans, the new private markets will have to remake their plans, meaning that the cost will rise and the plan we were told we could "keep" is in all likelihood no longer available.

Private health insurance is a low-profit industry with profit margins of about $4 \%$. With the additional costs of no lifetime caps and no exclusion for preexisting conditions, these companies will be compelled to raise their premiums to stay in business. The increased numbers of Medicaid participants are supposed to preserve profits but that seems unlikely, says Dr. Siegel, with all the new regulations.

Dr. Siegel provided this analogy: Imagine if your car insurance covered every scratch or dent. Wouldn't you expect your premiums to rise to meet the expanded coverage? And wouldn't you expect your auto repair shops to become clogged with cars that really didn't need to be repaired, competing for time and space with other cars with broken transmissions or burnt-out motors?

If we want lower insurance premiums, we will need to return to a system that favors high-deductible, high-copay catastrophictype insurance with a built-in disincentive for overuse. Patients could pay for office visits from health savings accounts or other flexible spending tax shelters. More than 10 million Americans already have such accounts. Unfortunately, the new law takes away the kind of insurance that compels patients to pay more themselves. As a result, medical care will cost more and be inferior to that provided today. Dr. Siegel concludes that the kind of insurance the new law mandates will, over the years, wear out the health care system.

\section{TODAY'S PRACTICES DESTINED TO FUTURE CONDEMNATION}

William Osler stated, "The philosophies of one age have become the absurdities of the next, and the foolishness of yesterday has become the wisdom of tomorrow." Kwame Anthony Appiah (29) has suggested four contenders for future moral condemnation.

The US prison system. Roughly $1 \%$ of adults in the USA are incarcerated. The USA has $4 \%$ of the world's population but $25 \%$ of its prisoners. No other nation has as large a proportion of its population in prison. China's rate is less than half that of the USA. Most of our prisoners are nonviolent offenders, many detained on drug charges. More than 100,000 inmates suffer sexual abuse, including rape, each year; some contract HIV. Our country holds at least 25,000 prisoners in isolation ("super max" facilities) under conditions that many psychologists say amount to torture.

Industrial meat production. Of the nearly 100 million cattle in the USA, at least 10 million at any time are packed into feedlots, saved from the inevitable diseases of overcrowding only by regular doses of antibiotics, surrounded by their own feces, their nostrils filled with the smell of their own urine. In the European Union, many of the most inhumane conditions we allow are already illegal or, like the sow stalls into which pregnant pigs are often crammed in the USA, will be illegal soon.

Institutionalized and isolated elderly. Nearly 2 million of America's elderly are in nursing homes, out of sight, and, to some extent, out of mind. Nearly 10,000 for-profit facilities have arisen in the USA in recent decades to hold them. Other elderly Americans may live independently but often are isolated and cut off from their families. Keeping aging parents close to their children is a challenge, particularly in a society where almost everybody has a job outside the home. Nevertheless, many old people, despite having many living relatives, suffer growing isolation.

Abuse of the environment. Our wasteful attitude toward the planet's natural resources and ecology is obvious everywhere. Desertification, which is primarily the result of destructive land-management practices, threatens a third of the earth's surface. Tens of thousands of Chinese villages have been overrun by sand drifts in recent decades. Vast expanses of portions of Russia, which decades earlier were a lush and verdant landscape, are now vast expanses of parched badlands. We know the harm done by deforestation, wetland destruction, pollution, overfishing, and greenhouse gas emissions. When our descendants inherit this devastated earth, they are unlikely to have the luxury of such recklessness. 
We should all have our own suspicions about which practices will someday prompt people to ask in dismay: "What were they thinking?"

\section{MICHAEL MILKEN ON OUR CHALLENGES}

In his forthcoming book Where is Sputnik?, Mr. Milken lists six challenging areas in the USA (30).

Housing. Investors have suffered some $\$ 1$ trillion in losses on supposedly safe mortgage-backed assets. Mr. Milken opines that we consider how many more jobs small businesses would have created if they had enjoyed the same terms we gave homeowners-easy access to 30-year, government-guaranteed loans at near-prime rates with no prepayment penalties. Those terms encouraged larger houses. The average size doubled in a generation to 2500 square feet, even as family size shrank. This required more land further from cities, and we bought bigger cars for longer, energy-wasting commutes. It was a great allocation of resources spurred by government policy and individual choices. We justified it on the theory that homeownership is a social good that builds personal responsibility and contributes to stable communities. But these ill-conceived policies produced the opposite: excessive consumer debt, irresponsible lending, mortgage defaults, unemployment, and declining neighborhoods. Ironically, a larger share of the population owns homes in many other countries where borrowers do not have a mortgage interest tax deduction and put up far more equity. American policymakers got it backwards. In the long run, jobs support housing, not the other way around.

Entitlement. Unrealistic promises of overgenerous health and retirement benefits forced General Motors, once the world's largest company, into bankruptcy. Unfortunately, the simple math of the GM situation applies to many institutions, including state and local governments that face massive pension commitments. And, looming even larger are the federal government's long-term obligations to recipients of Social Security and other entitlements. The problem is rooted in unrealistic assumptions about rates of return on assets; a falling ratio of current workers to retirees; workers who pay into the system for too few years; and pensioners who live longer than the original planners assumed. An important first step would be to periodically adjust the minimum retirement age to $85 \%$ of average life expectancy. Higher wage taxes and lower real benefits might follow.

Education. The Milken Family Foundation in 1982 began studying which factors have the greatest impact on student achievement. What they found was that teacher quality was far and away the most important school-related factor. We must hire and keep the highest-quality teachers possible. That requires powerful, embedded professional development, transparent and fair teacher evaluation, and performance-based pay.

Health. Out of every $\$ 10$ the USA collects in taxes, the government invests only a few pennies in research. We need more publicly supported research! We also should require more self-responsibility for our health. The Milken Institute's 2007 study, "An Unhealthy America," found that $70 \%$ of health costs (more than $\$ 2$ trillion a year) are related to lifestyle. Government programs are no substitute for personal responsibility in reducing the costs that flow from smoking, poor diets, and inadequate exercise.

Immigration. While the public debates center on undocumented low-skill workers, we should be equally focused on high-skilled professionals whom we have often shut out. More than half of Silicon Valley's science and engineering workforce is foreign born. Canada, the United Kingdom, and Australia encourage immigrant investors. China, Russia, Israel, and Singapore encourage the importation of smart entrepreneurs and scientists. Milken indicates that any nation that fails to welcome them will fall behind. Milken favors expanded visa programs for skilled workers and substantial investors who purchase property or create jobs. He believes we should grant permanent residency to graduates from accredited science and engineering programs.

Energy. In 1970, the USA imported about 36\% of its oil. We now import $60 \%$ of our oil. Energy security is at least as important as cotton and tobacco, whose prices we support. Oil needs similar support to avoid a repeat of the 1980s when many financial institutions and investors who responded to the call for energy independence were devastated by plunging prices. Lack of that support will discourage new investments and sustainable energy sources. Regrettably, the political hurdle is high because people want lower prices at the gas pump. We forget that we also pay for energy security with aircraft carriers, antiterrorism measures, environmental degradation, and, most tragically, military and civilian lives. Our competitors are directing increasing resources to human capital development and energy security. We have the capacity to match them, but do we have the will?

\section{TOO MUCH MONEY}

Mumbai (Bombay), India, is one of the largest and poorest cities in the world. But, Mumbai also has some very rich people. One is Mukesh Ambani, whose $\$ 27$ billion fortune ranks him among the richest people in the world (31). He has just built a 27-floor tower which will be the residence for his family, including his wife and their three children. Six of the 27 floors are a parking garage. Three helipads are on the roof. There are terraces upon terraces, airborne swimming pools, and hanging gardens. The tower reportedly cost $\$ 1$ billion. For decades, the Ambani family has been India's most famous corporate soap opera. The father, Dhirubhai Ambani, was a rags-to-riches tycoon who established Reliance Industries after rising out of the city's tenements. Today, Reliance is the world's largest producer of polyester fibers and yarns and accounts for almost 15\% of India's exports. The two sons, Mukesh and Anil, inherited and divided the empire and spent years feuding. Of Mumbai's 20 million population, $62 \%$ live in slums. High rises are considered inevitable and necessary given the peninsula city's limited land and swollen population. Something is wrong with all of this.

\section{HENRIETTA LACKS AND HER IMMORTAL CELLS}

In 1951 at the age of 30, Henrietta Lacks, a descendant of freed slaves, was diagnosed with an aggressive form of cervical 
cancer (32). Her doctor took a small tissue sample without her knowledge or consent. A scientist put the sample into a test tube and, though Henrietta died 8 months later, her cellsknown worldwide as $\mathrm{HeLa}$-are still alive today. They became the first immortal human cell line ever grown in culture and one of the most important tools in medicine. Research on HeLa cells was vital to the development of the polio vaccine as well as drugs for treatment of herpes simplex, leukemia, influenza, hemophilia, and Parkinson's disease; it helped uncover some secrets of cancer and the effects of the atom bomb and led to important advances like cloning, in vitro fertilization, and gene mapping. Since 2001, five Nobel Prizes have been awarded on research involving HeLa cells. No one knows exactly how many of Henrietta's cells are alive today. One scientist estimates that if you could pile all the HeLa cells ever grown onto a scale, they would weigh $>50$ million metric tons - the equivalent of at least 100 Empire State Buildings.

Today, nearly 60 years after Henrietta's death, her body lies in an unmarked grave in Clover, Virginia. But her cells are still among the most widely used in labs worldwide- bought and sold by the billions. Those cells have done wonders for science. Henrietta, whose legacy involves the birth of bioethics and the history of experimentation on African Americans, is all but forgotten.

\section{BOTOX AND MIGRAINE}

In October 2010 the Food and Drug Administration (FDA) approved Botox, the antiwrinkle shot from Allergan, as a treatment to prevent chronic migraines, a little more than a month after the company agreed to pay $\$ 600$ million to settle all allegations that it had illegally marketed the drug for unapproved uses like headaches for years (33). The agency's decision endorses use of Botox to treat patients with a severe form of migraine headaches occurring at least 15 days a month. Britain's drug agency approved Botox for the same use in 2010 .

Botox had worldwide sales in 2009 of about $\$ 1.3$ billion, divided equally between medical and cosmetic uses. The producer said sales of Botox for chronic migraines and other medical uses would soon eclipse sales of the drug as a wrinkle smoother. Allergan is also studying the drug for a variety of new medical uses, including overactive bladder. A Botox migraine treatment generally involves a total of 31 injections in the forehead, temples, back of head, neck, and shoulders. To treat the chronic condition, injections are given about every 3 months. It is estimated that the migraine treatment would cost $\$ 1000$ to $\$ 2000$, depending on the amount of drug used and the physician's fee. Some private insurers are likely to cover the migraine treatment now that it has received FDA approval. Some physicians are a bit leery of using Botox for chronic migraines, suggesting that it has only a marginal effect on headaches compared with a placebo.

\section{NOBEL PRIZE AND IN VITRO FERTILIZATION}

Robert Edwards of Britain won the 2010 Nobel Prize in medicine for developing in vitro fertilization (34). Edwards, an 85-year-old professor emeritus at the University of Cambridge, started working on in vitro fertilization in the 1950s.
He developed the technique in which eggs are removed from a woman, fertilized outside her body, and then implanted into the womb. He worked with British gynecologist Patrick Steptoe, who died in 1988. On July 25, 1978, Louise Brown in Britain became the first baby born through the groundbreaking procedure, marking a revolution in fertility treatment. Since then some 4 million have been born using the technique, a rate that is up to about 300,000 babies worldwide each year. Ms. Brown, now 32, gave birth to her first child in 2007. The boy was conceived naturally.

\section{MARRIED ADULTS VS UNMARRIED ADULTS}

For the first time since the USA began tallying marriages, more Americans of prime marrying age (25-34 years) have stayed single rather than marry (35). High divorce rates, rising cohabitation, and a tendency to delay marriage are the main factors. Although marriage rates among young adults have been dropping for decades, data released by the Census Bureau in September 2010 show that for the first time the proportion of people between the ages of 25 and 34 who have never been married exceeded those who were married in 2009 (46\% vs. $45 \%)$. The remainder is a mix of those who have lost spouses and divorcees who, if combined with the unmarried group, tilt the balance even further. The long-term slide in marriage rates has pushed the proportion of married adults of all ages to $52 \%$ in 2009 . In contrast, in $1960,72 \%$ of adults over age 18 were married. (The USA began tracking marriage statistics in 1880.)

The cities with the highest percentage of adults aged 25 to 34 who are married are Fort Worth, 52\%; El Paso, 51\%; Colorado Springs, 50\%; Las Vegas, 47\%; and Tulsa, 46\%. The cities with the highest percentage of adults aged 25 to 34 who have never married are San Francisco, 82\%; Boston, 82\%; Detroit, 80\%; Atlanta, $80 \%$; and Cleveland, $80 \%$. The change in marriage habits has been most pronounced among those with less education. Between 2000 and 2010 the share of young adults who are married dropped 10 percentage points to $44 \%$ among those who didn't attend college. Marriage rates among those in the same age group who hold bachelor's or more advanced degrees, meanwhile, fell $4 \%$ over that time to $52 \%$. This is a departure from past trends. In the past, college graduates were much more likely to postpone matrimony to focus on their career or further education. Now, a higher proportion of those without 4-year degrees are postponing marriage.

\section{GRANDPARENTS RAISING GRANDKIDS}

Roughly 7 million children live in households that include one grandparent, according to the most recent Census Bureau data from 2008 (36). Of that number, nearly 3 million were being raised by their grandparents, up $16 \%$ from 2000 . Reasons for grandparents' taking over childrearing duties are many and include a single parent who becomes overwhelmed with financial problems, is incarcerated, succumbs to illness or substance abuse, or dies. High rates of divorce and teen pregnancies fuel the phenomenon, as do long overseas deployments confronting some parents in the military. The American Academy of Child 
and Adolescent Psychiatry notes that many children living with grandparents enter that arrangement with preexisting problems (abuse, neglect, prenatal exposure to drugs and alcohol, and loss of their parents).

\section{PROHIBITION}

The 18th amendment to the Constitution was ratified on January 16, 1919. It reads as follows:

After one year from the ratification of this article the manufacture, sale, or transportation of intoxicating liquors within, the importation thereof into, or the exportation thereof from the United States and all territory subject to the jurisdiction thereof for beverage purposes is hereby prohibited. The Congress and the several States shall have concurrent power to enforce this article by appropriate legislation. This article shall be inoperative unless it shall have been ratified as an amendment to the Constitution by the legislatures of the several States, as provided in the Constitution, within seven years from the date of the submission hereof to the States by the Congress.

How did a freedom-loving people decide to give up a private right that had been freely exercised by millions since the first European colonists arrived in the New World? How did they condemn to extinction what was, at the very moment of its death, the fifth largest industry in the nation? With a single previous exception, the original Constitution and its first 17 amendments limited the activities of the government, not of citizens. Now there were two exceptions: you could not own slaves and you could not buy alcohol. Prohibition changed the way we lived, and it fundamentally redefined the role of the federal government. How in the world did it happen?

The answer comes in a wonderful book entitled Last Call: The Rise and Fall of Prohibition by Daniel Okrent (37). What follows was taken entirely from his 468-page book.

Alcohol in 19th-century America. America had been awash in alcohol almost from the start. In 1839, an English traveler described the role liquor played in American life:

I am sure the Americans can fix nothing without a drink. If you meet, you drink; if you part, you drink; if you make acquaintance, you drink; if you close a bargain, you drink; they quarrel in their drink, and they make up with a drink. They drink because it is hot; they drink because it is cold. If successful in elections, they drink and rejoice; if not, they drink and swear; they begin to drink early in the morning, they leave off late at night; they commence it early in life and continue it, until they soon drop into the grave.

Virtually every homestead in America had an orchard from which thousands of gallons of cider were made every year. In the cities, it was widely understood that common workers would fail to come to work on Mondays, staying home to wrestle with the aftershocks of a weekend binge. By 1830, the tolling of a town bell at 11:00 AM and again at 4:00 PM marked "grog time." Soldiers in the US Army received 4 ounces of whiskey as part of their daily ration since 1782 . And the propertied classes drank heavily also. George Washington kept a stile on his farm, John Adams began each day with a tankard of hard liquor, and Thomas Jefferson had his renowned collection of wines and rye whiskey made from his own crops. James Madison consumed a pint of whiskey daily.

By 1830, American adults were guzzling per capita 7 gallons of pure alcohol a year. In modern terms, those 7 gallons would be equivalent to 1.7 bottles of standard 80-proof liquor per person per week-nearly 90 bottles a year for every adult in the nation - even with abstainers factored in, and there were millions of them. If what Americans drank today was multiplied by three, that would give an idea of what much of the 19th century in the USA was like.

The beginnings of the temperance movement. The first prominent American temperance advocate was the Philadelphia physician Benjamin Rush, who encouraged the whiskey-riddled to consider a transitional beverage: wine mixed with opium or laudanum. (The word temperance at first meant moderation and later meant abstinence.)

The nation's first large-scale expression of antialcohol sentiment began in a barroom in Baltimore in 1840 when six habitual drinkers pledged their commitment to total abstinence. (It was later known as "the Washingtonian movement.") They abdicated no changes in the law; they refused to pin blame for their circumstances on tavern operators or distillers; they asked habitual drinkers only to sign a pledge of abstinence. In the same speech in which he condemned the ubiquity of alcoholic beverages, Abraham Lincoln, who thought mandatory prohibition a bad idea, praised the Washingtonian movement for its reliance on kind persuasion.

Neal Dow, a prosperous businessman from Portland, Maine, led a group of Portland employers who denied their workers their daily "eleveners" - grog time. Elected mayor in 1851, he immediately persuaded the Maine legislature to enact the nation's first statewide prohibitory law, mandating fines for those convicted of selling liquor and imprisonment for those engaged in its manufacture. The Maine Law, as it came to be known, enabled the antiliquor forces who had been stirred by the Washingtonians to use this template to pass similar laws in a dozen other states. By the end of the 1850s, however, states that had enacted versions of the Maine Law had repealed them, Maine included.

The movement reappeared in the 1870 s after Dr. Dioclesian Lewis spoke in December 1873 in Hillsboro, Ohio, a town of 5000 about 50 miles east of Cincinnati. Dio, as he was called, was not a physician - his MD was an honorary one granted by a College of Homeopathy_-but he was an educator, physical culturist, health food advocate, bestselling author, and one of the more compelling platform speakers of his day. In his lecture on alcohol he urged the women of Hillsboro to use the power of prayer to rid the town of its saloons, not only praying for the liquor sellers but praying with them. The next morning 75 Hillsboro women emerged in an orderly two-by-two column from a meeting at the Presbyterian church. At their head was Eliza Jane Tremble Thompson, the daughter of an Ohio governor, the wife of a well-known judge, and mother of eight. She 
was 57 and a devout Methodist. On that Christmas Eve and for 10 days afterwards, Thompson led her band to the town's saloons, hotels, and drugstores (many of which sold liquor by the glass). At each one, they fell to their knees and prayed for the soul of the owner. The women worked in 6-hour shifts, running relays from their homes to the next establishment on their list, praying, singing, reading from the Bible, and generally creating the largest stir in the town's history. If they were allowed inside, they would kneel on a sawdust floor that had been defiled by years of spilled drinks and the expectorations of men who had missed, or never tried for, the spittoon. If not, they remained outside singing and praying in the winter cold. In 11 days, Thompson and her sisters persuaded the proprietors of nine of the town's 13 drinking places to close their doors. By February 1874, federal liquor tax collections were off by more than $\$ 300,000$ in just two revenue districts. The events in Hillsboro launched a crusade that spread across the Midwest into New York and onto New England. In more than 110 cities and towns, every establishment selling liquor yielded to the hurricane set loose by Eliza Thompson. But, within a few months, this hurricane was spent.

Nevertheless, Mother Thompson, as she was referred to, set other women agitating against alcohol. Soon the new movement led by Susan B. Anthony and Elizabeth Cady Stanton also gave rise to the suffrage movement, which was a direct consequence of the widespread prohibition sentiment. The most urgent reasons for women to want to vote in the 1800 s were alcohol related: they wanted the saloons closed down or at least regulated. They wanted the right to own property, to shield their families' financial security from the profligacy of drunken husbands, to divorce those men and have them arrested for wife beating, and to protect their children from being terrorized by them. To do these things they needed to change the laws that consigned married women to the status of chattel. And to change the laws, they needed the vote. But the universal vote was decades away. Some women in the 1840s banded together to threaten sexual abstinence if their husbands could not achieve alcohol abstinence. Many rural and small-town women had to endure the dire ravages of the early saloon: the wallet emptied into a bottle; the job loss or the farm work left undone; and a scourge that late in the century was identified by physicians as "syphilis of the innocent" contracted by the wives of drink-sodden husbands who had found something more than liquor lurking in the saloons.

The Woman's Christian Temperance Union. Twenty years after Mother Thompson's crusade had subsided, the Woman's Christian Temperance Union (WCTU) was launched by Frances Willard (my daughter's married name). At age 35, Willard was among a small group of women who in 1874 founded the WCTU, and for the rest of her life she was field general, propagandist, chief theoretician, and nearly a deity to a 250,000 member army, undoubtedly the nation's most effective political action group in the last decades of the 19th century. Willard was raised on a farm in Janesville, Wisconsin. At 16, she asked her parents to sign a pledge she had pasted in the family Bible: "A pledge we make, no wine to take, nor brandy red that turns the head ... so we pledge perpetual hate to all that can intoxicate." A few years later Willard moved to Evanston, Illinois, with her family. The town was dominated by New College (later Northwestern University) founded by a legal proscription against the sale of alcoholic beverages within 4 miles of its campus and buttressed by the creation of a similarly liquorloathing women's school that opened nearby. Willard graduated from Northwestern Female College as valedictorian and became its president a decade later. The two schools merged in 1873. In 1874 on a trip east, Willard found herself on her knees in a saloon on Market Street in Pittsburgh singing "Rock of Ages." A few weeks later, she walked away from her academic career so she could give her life to the temperance cause.

Willard made temperance a woman's issue. She further believed that temperance was not enough. Only some form of legal prohibition could crush the liquor demon, and no prohibition would ever be enacted without the votes of women. In 1876, she told a WCTU audience that women should have the right to vote on matters relating to liquor. Willard urged her followers to agitate for a set of goals that stretched far beyond the liquor issue. She campaigned for suffrage; prison reform; free kindergarten; vocational schools; an 8-hour work day; workers' rights; government ownership of utilities, railroads, factories, and theaters; vegetarianism; cremation; less restrictive women's clothing; and alcohol-free, tobacco-free, lust-free marriages. Her determination to connect prohibition (the legislated imposition of teetotalism on the unwilling) to other reforms also was being propagated by the Prohibition Party in its first national campaign, which was in 1872 . The party endorsed universal suffrage, public education, and the elimination of the electoral college, among other issues.

Frances Willard invited Mary Hanchett Hunt, a former chemistry teacher from Massachusetts, to speak at the WCTU Convention in 1879. Hunt believed it her mission to reach the nation's children, to saturate them in facts-as she perceived them - that would make young people despise alcohol as much as she did. Through them, Hunt enlisted the WCTU's battalions in an assault on the nation's school boards with a program of "scientific temperance instruction," which she intended to introduce into every American schoolroom. With Willard's support, Hunt sought to have two or more monitors from every WCTU chapter lay siege on their local school boards. From there, she targeted state legislatures, beginning in 1881. She became known as the "queen of the lobby." Vermont in 1882 was the first state to pass a compulsory temperance education law, followed later by many other states. By 1901, when the population of the entire country was about 80 million, compulsory temperance education was on the books of every state in the nation, and all 22 million American children and teenagers had three weekly lessons on temperance. In Boston, Hunt also created the "Scientific Temperance Museum." Professor Charles H. Stowell of the University of Michigan Medical School, a stalwart antialcohol man, authored a series of health and anatomy books supported fully by Hunt. In his textbook for high school students, he described alcohol as "a narcotic poison with the power to deaden or paralyze the brain." 
Carry Amelia Moore Gloyd Nation, 6 feet tall with the biceps of a stevedore, was the next of the major prohibition leaders. The hatchet made her famous, and she used it to destroy a saloon. The hatchet soon transformed itself from weapon to symbol to calling card for her career as a platform speaker. Through her prohibition lectures, which she delivered on the vaudeville circuit, she had a major impact.

Saloons and breweries. By the end of the 19th century, production and consumption of whiskey and other distilled spirits had declined substantially, to a per capita figure not radically dissimilar from what it would be 100 years later. In 1850, Americans annually averaged drinking 36 million gallons of beer; by 1890 , annual consumption of beer had increased to 855 million gallons. During that 4-decade span, while the population tripled, that population's capacity for beer had increased 24-fold. Immigration was the main reason. Those coming from Ireland and Germany loved the "liquid bread." And of course the settlement of the West provided numerous more saloons. The number of saloons in the USA increased from 100,000 in 1870 to nearly 300,000 by 1900 . In Leadville, South Dakota, population 20,000, there was one saloon for every 100 inhabitants - women, children, and abstainers included. San Francisco in 1890 had one saloon for every 96 residents. In Manhattan there were 4000 saloons for every 100 churches.

The typical saloon featured more than just drink and companionship, particularly in urban immigrant districts and in the mining and lumber settlements. In these places, where customers' ties to a neighborhood might be new and tenuous, saloon keepers cashed checks, extended credit, and supplied a mailing address or a message drop for men who had not yet found a permanent home. And in some instances, saloons provided sleeping space at $5 \$$ a night. Some saloon keepers were labor contractors for dock workers. Many saloons had the only public toilets or washing facilities in the neighborhood. By the 1890s, most saloon keepers had complimentary spreads to lure customers and promote the sale of beer. These saloons had nice paintings (Custer's Last Fight was the most popular) or large mirrors, nice furniture, brass foot rails, iron and porcelain spittoons, and nice glassware.

These ornaments were provided by the breweries. The surest way a brewer could secure his piece of the local action was through the "tied house." If a saloon operator would agree to serve only one brand of beer, the brewer would provide cash, loans, and whatever other emoluments were necessary to furnish the place, stock the lunch table, meet the license fee, and when necessary line the pockets of politicians. By 1909, 70\% of American saloons were owned by, in debt to, or otherwise indentured to the breweries.

The antiprohibition campaigns, of course, were levied by the brewers, the most prominent of whom was Adolphus Busch, the youngest of 21 children of a prosperous Rhineland merchant. Busch immigrated to the USA in 1857, went into the brewery supply business, and in 1861, at age 22, married Lilly Anheuser, the daughter of one of his customers. Adolphus' brother, Ulrich, married Lilly's sister, Anna. Adolphus soon took over the management of his father-in-law's company and in time appended his surname to it. Busch also built glass factories and ice plants and acquired railroad companies to ferry coal from mines to the vast Anheuser-Busch factory complex in St. Louis. Busch got into the manufacture of refrigerated railcars and truck bodies that could be used not just by breweries but also by customers such as meat-packing companies. He got exclusive US rights to a novel engine technology developed by his countryman, Rudolph Diesel. In 1875, Busch produced 35,000 barrels of beer; by 1900 his annual output surpassed a million barrels. In 1903, he helped craft an agreement essentially signed by nine breweries to fund a committee "promoting antiprohibition matters in Texas" such as paying poll taxes of black and Mexican Americans who were expected to vote for legal beer. He purchased the editorial support of newspapers. Busch died at the age of 74 from cirrhosis of the liver.

The Anti-Saloon League. The Anti-Saloon League (ASL) was founded by Howard Hide Russell, who in his early 20s was a prosperous lawyer in Iowa but at age 28 entered the Theology School of Oberlin College in Ohio. The Oberlin community possessed deep convictions, and at one point dietary restrictions were so severe at the college that in addition to alcohol, tea, coffee, and meat, the list of proscribed foods included pepper, gravy, and butter. Ordained at age 31, Russell occupied ever larger pulpits and at age 36 founded the ASL. Driven by focus and intimidation, the league declared war on alcohol and only on alcohol — only one target, a direct rebuke to the unfocused efforts of both the WCTU and the Prohibition Party. Frances Willard's "do everything" policy had been distracting. The ASL cared only about alcohol and about freeing the nation from its grip. There would be one big question mark before the name of every candidate for public office: "Is he right on this question?"

To gather support needed to fund the group's effort, Russell and his colleagues mobilized the nation's Protestant churches and their congregations. The ASL slogan read: "The church in action against the saloon." The leadership, the staff, and the directorates of the ASL and its affiliate organizations were overwhelmingly Methodist and Baptist. The clergymen occupied a minimum of $70 \%$ of the board seats of any state branch. It set out to reach the hundreds of thousands of churchgoers in church and through their pastors. Once the ASL had established its network of churches, it did not take long for it to replace the WCTU at the head of the prohibitionist movement.

In 1908, the Reverend Purley A. Baker, a fearsome Methodist preacher from Columbus, succeeded Howard Russell as the ASL's national superintendent. Baker was the one who hired Wayne Bidwell Wheeler, an Oberlin College graduate, who was penniless when he arrived there in 1890. (He died in 1927 at age 57.) He was 65 inches tall and, at the peak of his power, looked more like a clerk in an insurance office than a man who, as described by the Cincinnati Enquirer, "made great men his puppets." Wheeler was one of ASL's first full-time employees. One classmate had described him as a "locomotive in trousers." While attending Western Reserve Law School, he worked fulltime for the ASL. After earning his law degree in 1898, he took over the Ohio ASL legal office. His productivity accelerated, and 
his responsibilities steadily increased. By 1901, the Ohio ASL had 31 full-time paid staff members coordinating a legion of zealous pastors. John D. Rockefeller, a lifelong teetotaler as well as America's wealthiest Baptist, financially gave $10 \%$ of whatever the league was able to raise from other sources. Wheeler was described by one of his associates as the figure who

controlled six Congresses, dictated to two presidents, directed legislation for the most important elective state and federal offices, held the balance of power in both Republican and Democratic parties, distributed more patronage than any dozen other men, supervised a federal bureau from the outside without official authority and was recognized by friend and foe alike as the most masterful and powerful single individual in the United States.

By 1909, the ASL had over 800 business offices and at least 500 men and women on regular salary. Additionally, it employed large numbers of speakers on contract, from the governor of Indiana down to the local pastor of the Methodist church.

Political issues and taxes related to prohibition. Just as the urban saloon served as mail drop, hiring hall, and social center for the immigrant masses, so too was it birthplace, incubator, and academy for the potent political machines that captured control of the big cities of the East and Midwest in the last quarter of the 19th century. In New York in 1884, 12 of the 24 members of the board of alderman owned saloons, and four others owed their post to saloon backing. The same was true in Detroit, Chicago, and other big cities.

For prohibition to become the law of the land, it had to connect with certain other groups who were pushing other issues. Tax on alcohol made up a large portion of federal revenues. A tax on alcohol maintained our revolutionary army against the British. This tax lapsed in 1802, was reimposed by James Madison to pay for the War of 1812, was suspended in 1817, and was brought back by Abraham Lincoln in 1862 to finance the Civil War. After that, the tax did not fade away when the war ended. It had spawned an underground tax-free trade in an illegal substance that would forever be known as "moonshine" and a collection apparatus staffed by men from the Bureau of Internal Revenue, known as "revenuers." For most of the 30 years the imposte on alcohol annually provided at least $20 \%$ of all federal revenue; in some years, it provided more than $40 \%$. By the time the excise was doubled to cover the cost of the Spanish-American War, the brewers had finally realized that the tax might be their salvation, and they patriotically declared that they had financed $40 \%$ of the war's cost. By 1910 , the federal government received more than $\$ 200$ million a year from the bottle and the keg- $71 \%$ of all internal revenue and more than $30 \%$ of all federal revenue. Only the tariff provided a larger share of the federal budget.

Thus, for prohibition to become law, the USA needed to create a tax on income. No one was better equipped to yoke these two causes together than William Jennings Bryan, the dominant leader of the Democratic Party from 1896 until 1912. Bryan was devoutly religious and avoided alcohol his entire life. To the devoted admirers that backed him in his three failed presidential campaigns, he was the peerless leader and later "the great commoner." Between 1913 and 1919, amendments establishing income tax, direct election of senators, prohibition, and women's suffrage were engraved in the nation's Constitution, and Bryan was in the forefront in the campaign for each. Imposition of an income tax was an absolutely necessary step for the prohibitionists if they were going to break the federal addiction to the alcohol excise tax. By the time Congress voted to approve a constitutional amendment authorizing income tax (1913), the Anti-Liquor Caucus and the Pro-Tax Caucus were fully together.

The movement toward a constitutional amendment. Until 1913, the ASL had focused on state-by-state prohibition laws, but in that year, Congress overrode a veto by William Howard Taft of the Webb Kenyon Act, a measure outlawing the importation of alcoholic beverages into a dry state. The passage moved the ASL's new goal to national prohibition and the adoption of a constitutional amendment. Each month thereafter, more than 40 tons of prohibitionist propaganda was published each month by ASL. The policy statement announcing ASL's commitment to the amendment strategy was entitled "The Next and Final Step." By delivering his voters to one candidate or another in a close race, Wayne Wheeler controlled elections. "We'll vote against all the men in office who won't support our bills. We will vote for candidates who will promise to." A constitutional amendment required legislative majorities in 36 states as well as the two-thirds majorities in both houses of Congress. Acquiring these numbers required all the talents of Wayne Wheeler, and he had them. The adoption of the tax amendment and subsequent passage of the Revenue Act of 1913 confirmed the virtual collaboration with other interest groups, but the ASL's partnership with women who backed a suffrage amendment proved the most important collaboration. The suffrage movement brought the prohibition movement to the brink of success. A congressional resolution calling for a prohibition amendment to the Constitution had been introduced in every Congress since 1876, but none had ever emerged from committee. In 1914, both the prohibition amendment and the universal suffrage amendment were reported out of committee on the same day. They had become welded to each other. Jack London, who both drank to excess and maybe wrote to excess, believed that "the moment women get the vote in any community, the first thing they proceed to do is close the saloons" and, therefore, "when no one else drinks, and when no drink is obtainable," he would finally be able to stop drinking. London wanted the suffrages to vote him into sobriety. In 1916, the ASL formally endorsed woman's suffrage - the only time in its history it violated its single-issue pledge.

A key member of the prohibition movement was Richmond Hobson, who had won renown as a Spanish-American war hero for his bravery while commanding a failed mission aboard the USS Merrimack in Cuba. After that he began a lecture tour, and it was apparent that his auscultatory skill matched his military powers. He was an irresistible orator. He entered the House of Representatives in 1906 and not only did he oppose alcohol, he opposed the tariff, sought to break up 
the industrial trusts, introduced the resolution calling for the abolition of the electoral college, and supported both the income tax and women's suffrage. His defining issue, however, the one that made him one of the most popular platform speakers of the day, was the elimination of the trade in alcoholic beverages. Hobson became the floor manager of the constitutional amendment for prohibition. He argued that his amendment forbade only the use, manufacture, and transportation of alcohol "for sale." It was not coercive; it would not prevent men and women from making and drinking their own. He stressed that he was not asking members to vote for or against alcohol, only to allow the state legislatures the opportunity to pass judgment on the amendment. Therefore, he insisted, any congressman who voted against the resolution would be wrong "to deny the states their right, a referendum." The final vote on the Hobson Amendment was 197 for, 190 against-not the two-thirds majority the Constitution required, but an astonishing result nevertheless. That was December 22, 1914.

The 1915 ASL Convention took place shortly after the symbolic triumph of the Hobson Amendment warmed old campaigners and drew new ones. John L. Sullivan, the heavyweight champion, spoke on behalf of the cause. Dr. J. H. Kellogg, the famous physician from Battle Creek who had placed cornflakes on the American breakfast table, came to speak. Booker T. Washington was another speaker. One speaker quoted British Prime Minister David Lloyd George, whose country had been at war for a year: "We are fighting the Germans, the Austrians, and drink. And the deadliest of these is drink." Although Lloyd George never tried to institute actual prohibition in Britain, he did increase the excise taxes 7-fold on alcohol, and the imposition of the peculiar schedule of pub closing hours was not revoked until 2005. Other countries, including France, Sweden, Germany, Iceland, Spain, Norway, Finland, Russia, and Canada (save for Catholic Quebec), all instituted some kind of prohibition laws during World War I.

Just 5 days before the Hobson Amendment's failure, Congress had enacted a much more modest measure called the Harrison Narcotics Tax Act. The law empowered the Internal Revenue Service to tax, and thus to regulate, opiates, coca derivatives, and other drugs. The Harrison Act conferred on the federal government powers on matters of personal behavior. This act was the logical precedent for federal regulation of the liquor traffic.

By 1916, the ASL's printing machine was pouring out more than 10 tons of printed paper daily. In addition, the league had a massive speakers operation, with more than 20,000 trained lecturers ready to deliver the ASL gospel and to reap the ASL tithe. The league's honorarium men-the highly paid speakers who drew the largest audiences and could raise the largest sums-were generally the driest of the congressional drys. But the biggest draws were two men no longer in public office, William Cullen Bryan and Richmond Hobson. In a single week in 1915, delivering an average of 10 speeches a day, Bryan addressed more than 250,000 Ohioans. In Ann Arbor, 5000 students turned out to hear him; in Philadelphia, he had 20,000 listeners and begged the assembled on his knees to pledge total abstinence. The "Great Destroyer," Richmond Hobson, gave 83 speeches for the ASL in a single summer. By November 1916, election day, the ASL's leadership, its publicists, and its 50,000 lecturers, fundraisers, and vote counters on the front lines had completed their work. The ASL had made it safe for candidates to be dry. The dry laws were now on the books in 23 of the 48 US states.

After the 1916 election, prohibitionism attracted still more allies, including Asa Candler, founder of the Coca-Cola Company (a very close friend of my father's father), and Lee Schubert, the owner of several of Broadway's theaters and bars. The only wets left were the "Stand Pat" Republicans in Congress who generally opposed the income tax, the vote for women, child labor legislation, and anything else that transferred an ounce of power to the federal government. With few respectable allies, the brewers, distillers, wholesalers, and dealers for a time attempted to recast their own image but failed.

Back in 1912, when the formal push for the prohibition amendment was launched, before the ratification of the 16th (income tax) and 17th (direct election of senators) amendments, ASL's leaders were setting themselves a historically daunting task. Except for the three amendments enacted during the aftershocks of the Civil War, the Constitution had been amended only twice in the preceding 118 years. It was one of those Civil War amendments that opposed the last roadblock to congressional approval of constitutional prohibition.

The South may have been the part of the country with the most intense antiliquor sentiment and the widest range of state liquor laws. In Alabama, for example, liquor advertisements of any kind were forbidden, even in out-of-state newspapers that circulated within the state. But despite the white South's general sympathy for the dry cause, its distinctive politics-particularly its wide attachment to the concept of state rights-compelled the ASL to devise a distinctive lobbying approach. It also required a distinctive lobbyist to carry it out, and that was Reverend James Cannon, "the dry messiah." He was a Methodist minister in Virginia, and by his early 40s he had become one of the most dominant individuals in the public life of the state. He was the principal of Blackstone Female Institute, a 2-year college in the south central part of the state. He engineered in 1914 the Temperance Forces in the Commonwealth to a successful statewide dry vote. After that, the ASL came calling. In contrast to the "dry-drys," the "wet-drys" were especially abundant in southern Democratic politics. As Wayne Wheeler had said, "Wet-drys are men who vote as they pray rather than as they drink." The worry for the ASL was that southern Democrats had a higher loyalty to state rights than they did to prohibition, and the pending prohibition amendment would logically require them to accept the validity of an amendment already in the Constitution-the 15 th, affirming the voting rights of all men, black and white. In the end, though, when the 18th amendment was brought to a vote in the House of Representatives in December 1917, James Cannon and his colleagues were able to pry from the wet column nine southern and border state House Democrats 
who had voted against the Hobson Amendment in 1914, and they lost none going the other direction. Although the final vote of 218 to 128 seemed a landslide, in requiring a two-thirds majority, the Constitution demanded a landslide; without the nine who had migrated from "wet" to "dry" the resolution that had passed the Senate with ease would have died in the House. The promising young Sam Rayburn of Texas was among those who made the switch. (Rayburn would remain in Congress another 44 years, for 17 of them as speaker of the house.)

As it traveled its path from the Hobson Amendment of 1914 to another one in 1917, prohibition leapt ahead of universal suffrage in the reform queue. It also underwent substantial legislative tinkering. The debate was not about prohibition, the drys tried to say, it was only about "submission" of the amendment to the states where two-third majorities in both houses of Congress were needed so the states would have a chance to decide for themselves in the ratification process. The Senate Judiciary Committee did not even bother with hearings; neither had its House counterpart. Floor debate in the Senate was largely given over to an argument over timing. The House crammed its discussion of the resolution into a single afternoon. The real debate had been taking place for more than 60 years.

In addition to the congressional wets, a few moderate drys whose votes were still somewhat in question wanted to provide compensation to the distillers and brewers, much of whose property was about to become worthless. In 1917, 13 million gallons of bourbon were aging in Kentucky warehouses alone. Nationwide, the liquor and beer industries represented nearly $\$ 1$ billion in invested capital, by that measure making the combination the nation's fifth largest industry! The no-compensation argument eventually prevailed. One of the conciliatory drys who had supported the idea of compensation was William G. Harding, the junior senator from Ohio. Harding was about as moist as a dry could get, both in his attitude and in his personal life (he favored scotch and soda and owned stock in a brewery). Harding not only believed that the liquor interest deserved compensation, but also felt that there should be a cap on how much time the states were allowed for ratification, a constraint that had never been applied to previous amendments. Harding suggested 5 years but Wheeler stretched it to 7. In exchange, Harding and the other moderates got a new opening clause to the amendment, stipulating that its provisions would not take effect until 1 year after its ratification. This gave a 12-month grace for the brewers and distillers, the wholesalers, the saloon owners, the bartenders, the barrel makers, the bottlers, the teamsters, the ice dealers, and all the other people dependent on the American taste for alcoholic beverages. This grace period was a facsimile of compensation.

One of the major players in making the prohibition amendment possible was William Ashley Sunday (Billy Sunday). He played baseball for the Philadelphia Phillies until 1890 when he put away his glove, bat, and spikes. He had just completed a season in which he had stolen 84 bases and earned $\$ 3500$, roughly nine times the wages of the average American industrial worker at the time. But he loved Christ and he hated alcohol and he decided to turn away from the sporting life and preach. He became an evangelist and the most successful American preacher of his era, perhaps the most successful one ever. It is said that Billy Sunday preached to more than 100 million people in his 40 years in the pulpit. Sunday's speeches were devoted first to his fundamentalist view of Jesus; his fanatic opposition to the beer and liquor interest came a close second. To Billy Sunday, liquor was "God's worst enemy" and "hell's best friend," and he considered those who profited from the alcohol trade earthly satans. He said, "I will fight them till hell freezes over." The liquor interest hated Billy Sunday. A magazine poll in 1914 attempted to determine who was "the greatest man in the United States." Sunday placed eighth, tied with Andrew Carnegie. He gave as many as 250 speeches a year, addressing the enormous audiences he could command in the late 1910s. Sunday gave shape to the new attitude-increasingly ferocious, even vengeful - that characterized the prohibition forces as they stood at the edge of victory.

Prohibition efforts and World War I. After the 18th amendment was ratified, resentful wets frequently expressed the belief that World War I, which exploded in Europe in 1914 and which the USA entered in 1917, was especially great for the ASL and its allies. Although a myth, the wets attributed the amendment's adoption to the absence of 2 million soldiers from American shores and voting booths. Further, the series of War Revenue Acts that Congress passed at Woodrow Wilson's request, which increased liquor taxes to help finance the war effort, in effect made the purchase of alcohol beverages in the early days of World War I a patriotic act. The populist, antibusiness, Bryan-led wing of the dry coalition, capitalizing on the looming disappearance of liquor tax revenues, used the war crisis to usher in sharply progressive income tax rates. (By the time prohibition took effect, the highest bracket had been jacked up past $70 \%$, more than six times the prewar level.)

The month the USA entered the war (April) the distinguished Yale economist Irving Fisher assembled a group of famous Americans, few of them previously associated with the movement, to endorse the need for national prohibition. The lineup included novelists Upton Sinclair and Booth Tarkington, aviation pioneer Orville Wright, and the chairman of US Steel. Fisher parlayed his renown by issuing an analysis of the damage being done to the war effort by the wanton waste of food resources. The same amount of barley used in American breweries could instead yield 11 million loaves of bread a day. Bryan later said, "How could we justify the making of any part of our bread stuff into intoxicating liquors when they could nourish the army and feed the starving Belgians?"

Between April 1917 and November 1918 - the length of US involvement in World War I-a series of "for-the-duration" laws, proclamations, and executive orders first outlawed the sale of alcohol to soldiers and then proscribed the importation of 
distilled spirits and forbade their manufacture. Dry zones were established around naval bases and around coal mines, shipyards, and munitions plants. In the name of the war effort, food administrator Herbert Hoover ordered the amount of grain available to the brewery industry reduced by $30 \%$. Legal beer was limited to $2.75 \%$ alcohol by weight. The war emergency handed proponents of government activism essentially a hunting license to "seize railroads, requisition factories, take over mines, fix prices, put an embargo on all exports, commandeer all ships, standardize all loafs of bread, punish all careless use of fuel, draft men for an army, and send that army to a war in France." Compared to all that, the closing down of distilleries and breweries didn't seem too dire after all. The war also produced an anti-German hysteria in the USA. All the large breweries in the USA had German-American heads: Pabst, Schlitz, Blitz, and Miller. Germanism meant antiAmericanism, and by Wheeler's conflation it also meant "wet."

Ratification of the amendment. As 1917 drew to a close, submission had been accomplished. Ratification seemed a more daunting prospect. By this time, 23 states had dry laws of one form or another, although few were as "bone dry" as the 18th amendment. Looming ahead was the trench warfare of the state-by-state ratification in which the drys would need to win a minimum of 36 separate battles to reach the three-quarters requirement. In the end, ratification proceeded with astonishing speed. The income tax had made a prohibition amendment fiscally feasible. The social revolution wrought by the suffragists had made it politically plausible. The war was the final tool the drys needed to wage the amendment into the Constitution.

On January 8, 1918, the 33 members of the Mississippi State Senate and the 96 members of the State House gathered in Jackson to vote on the 18th amendment to the Constitution. The vote, which proceeded without debate, took exactly 15 minutes, passing 28 to 5 in the upper house and 93 to 3 in the lower one. Mississippi was much more agreeable to this second constitutional amendment ever to place limits on individual behavior than it was to the first one. It didn't get around to ratifying that one-the 13th, abolishing slavery-until 1995!

The universal malapportionment of state legislatures was helpful in the ratification process. In New York, for example, the legislature was configured so that an urban assemblyman might represent seven times as many people as the rural representative. But, the vote of a farmer from upstate Preston Hollow—more likely native born, Republican, and dry—was equivalent to the vote of seven Democratic, Irish American wets from Hell's Kitchen in Manhattan. In New Jersey, where each member of the state senate represented a single county irrespective of its population, the man from Cape May County served just 20,000 constituents while his colleague from Essex County represented 650,000. The farmers and fisherman who controlled Maryland's legislature had conspired to avoid any redistricting since 1867 . In the intervening decades, while the population of urban ethnic Baltimore had jumped $175 \%$, the population in the rest of the state had only increased $46 \%$. By 1918, democracy in Maryland had been imprisoned for half a century. That same type of distribution occurred in numerous other states at the time.
The state legislators had the authority to enact constitutional prohibition, and with their rural domination they did so with the speed of an epidemic, immune from referenda or gubernatorial vetoes. More than $80 \%$ of the nation's state legislators voted dry. The more rural the state, the more arid the vote. Among the six states whose legislators were unanimous for ratification were Idaho, Kansas, South Dakota, Utah, and Wyoming.

On January 16, 1919, when Nebraska's lower house went 98 to 0 for prohibition, the 18 th amendment was embedded in the US Constitution. From that moment of submission, it had taken 394 days to meet the approval of 36 state legislatorsless than half as long as it had taken 11 of the first 14 states to approve the Bill of Rights.

Life after prohibition. The opening clause of the 18th amendment- "After one year from the ratification of this article"-meant that life in the USA was no different on January 17, 1919, from what it had been on January 16. Immediately after ratification, H. L. Mencken sold his 1915 Studebaker and told a friend that he "invested the proceeds in alcohol." Harry S Truman, fighting in Europe, wrote to Bess Wallace: "It looks to me like the moonshine business is going to be pretty good in the Land of the Liberty Loans and Green Trading Stamps and some of us want to get in on the ground floor. At least we want to get there in time to lay in a supply for future consumption." He was on target. The experience of states that had already gone dry suggested there was a large and liquid gulf between how people voted and how they drank. William Howard Taft, serving in the interval between his presidency and his chief justiceship of the Supreme Court, said, "The business of manufacturing alcohol, liquor and beer will go out of the hands of law-abiding members of the community and will be transferred to the quasi-criminal class." As Daniel Okrent stated, "The only ill chosen word in that sentence was 'quasi."”

The man whose legislative skills were called upon to prevent the realization of Taft's prediction was Andrew John Volstead, whose name would forever be attached to prohibition. Webster's recent unabridged dictionary defined Volsteadism as "the doctrine of or adherence to prohibition." He was the one who sponsored the legislation required to enforce the 18th amendment. He had been in the House 16 years before assuming the chairmanship of the Judiciary Committee and therefore was responsible for the National Prohibition Act, which was the formal name of the legislation that would turn the 18th amendment's declaration into a code of enforcement.

The Volstead Act eventually had 67 separate sections. The final bill covered everything from the definition of "intoxicating" (its single most crucial sentence) to whether dealcoholized beer could still be called beer or "near beer," to whether a foreign ship would be allowed to pass through the Panama Canal. Volstead (and Wheeler) spent several months crafting a measure so tight that not one of its provisions was ever deemed unconstitutional. What was carefully kept out of the criminal code was any specific prescription against drinking or buying alcohol; savage drys knew that without this enormous carveout no user would ever testify against his supplier. The phrase "intoxicating liquors" won out over "alcoholic beverages" in 
the amendment itself. This conscious dodge had enabled fence sitters, conflict avoiders, and wishful thinkers to support the amendment in the hope that the eventual definition would leave room for some of the milder forms of stimulation.

To pass the Volstead Act, only a majority was needed in each House of Congress, rather than two thirds of each House plus three quarters of the state legislatures. The word "intoxicating" was defined as anything ingestible that contained more than $0.5 \%$ alcohol content. This proscribed the lightest of wines and the most diluted forms of beer, but exceptions were placed in the Volstead Act to render it less than absolute. The orthodox Jews and the Catholics came away with continued access to sacramental wines for their congregations. Many hardline drys wanted to deny physicians the right to prescribe alcohol, but this too wasn't worth the fight. No one questioned the need for the continued production of industrial alcohol for its many critical and/or popular uses. In a nod to those who had invested in their personal cellars (including various dry senators and representatives), the act allowed individuals to continue to own and to drink in their own homes any alcohol that was purchased before the 18th amendment's effective date.

The Volstead Act specifically exempted cider and other "fruit juices" that just might happen to acquire an alcoholic tinge through the natural processes of fermentation. They were not subject to the $0.5 \%$ ceiling. The law made home manufacture of hard cider perfectly acceptable. No husbandman would be denied the barrel by the homestead door, the jug stashed in a corner of the field, the comforting warmth on cold country nights. Alvin Barker of Kentucky, who later became vice president, noted that if it was legal to transfer the juice of the apple into something stronger, then "why not corn juice?"

The Volstead Act failed to provide a judicial procedure other than trial jury for anyone accused of any violation, dooming the federal court system to an unremitting 14-year flood of petty cases. The army of federal agents hired to enforce the act would not be part of the civil service because Andrew Volstead, among others, feared that civil service protection would guarantee "the offices would be filled with wets that we could not get rid of." The total initial appropriation for federal enforcement of this radical and far-reaching new law amounted to $\$ 2.1$ million.

By the time the Volstead Act had become law, the drys had become giddy in their political dominance and confident they would retain power sufficient to correct any errors or omissions. The prohibition amendment was the culmination of 50 years of continuous effort by the drys. In contrast, the wets were disorganized, dysfunctional, and disbelieving. But now they had to adjust. In 1921, Andrew J. Volstead told his House colleague, John Garner, that although "we will gradually work out the machinery that will, with the cooperation of the states, make the country dry, we cannot hope that this law can be enforced so as not to be violated. All laws will be violated." The product of 80 years of marching, praying, arm twisting, vote trading, and law drafting would be subjected to a plague of trials, among them hypocrisy, greed, murderous criminality, of- ficial corruption, and the unreformable impulses of human desire. The drys had their law, and the wets would have their liquor.

The liquor industry was not dead. The new version was illegal, underground, and nearly ubiquitous. But many Americans began to drink less. A significant proportion of the population either felt duty bound to take the constitutional strictures seriously or found the procedural roadblocks elected by the Volstead Act too daunting. Alcohol-related deaths fell in 1920, as did arrests for public drunkenness. Welch's Grape Juice began to set new sales records. Diminished criminal behavior occurred in several cities. Many neighborhoods registered a general lack of street disorders and of family quarrels. Songwriter Albert von Tilzer, who had taken America out to the ballgame in 1908, had a new song, "I Never Knew I Had a Wonderful Wife Until the Town Went Dry." But in the decade after the arrival of the 18th amendment, alcohol consumption in the USA dropped only $30 \%$ !

So why did prohibition fail? It encouraged criminality and institutionalized hypocrisy. It deprived the government of money. It imposed profound limitations on individual rights. It fostered a culture of bribery, blackmail, and official corruption. It also maimed and murdered. But in one critical respect, prohibition was an unquestioned success. As a direct result of its 14-year reign, Americans drank less, and they continued to drink less for decades afterward. Back in the first years of the 20th century, before most state laws limiting access to alcohol were enacted, average consumption of pure alcohol ran to 2.6 gallons per adult per year- the rough equivalent of $32 \mathrm{fifths}$ of 80 -proof liquor or 520 bottles of 12-ounce beer. Judging by the most carefully assembled evidence, that quantity was slashed by more than $70 \%$ during the first few years of national prohibition. It started to climb as American thirst adjusted to the new regime. But even repeal did not open the spigots: the preprohibition per capita peak of 2.6 gallons was not again obtained until 1973. (It stayed that high only until the mid1980s, when it began to drop again to current levels of roughly 2.2 gallons per person per year.)

Repeal of prohibition. In the surprisingly slow growth of postprohibition drinking lay the central irony of repeal: the 21 st amendment made it harder, not easier, to get a drink! During the latter stages of prohibition, especially in the big cities or near the coasts or adjacent to the Canadian border, little effort was required to obtain a drink, a bottle, or in some places even a shipment of contraband. What was formerly illegal was necessarily unregulated. Repeal changed that, replacing the almost-anything-goes ethos with a series of state-by-state codes, regulations, and enforcement procedures. Now there were closing hours, age limits, and Sunday Blue Laws and a collection of geographic proscriptions that kept bars or stores distant from schools, churches, or hospitals. State licensing requirements forced legal sellers to live by the code, and in many instances statutes created penalties for buyers as well. Just as prohibition did not prohibit making drink legal, its repeal did not make drink entirely available. 
The 21st amendment to the US Constitution, enacted in 1933, reads as follows:

The eighteenth article of amendment to the Constitution of the United States is hereby repealed. The transportation or importation into any State, Territory, or possession of the United States for delivery or use therein of intoxicating liquors, in violation of the laws thereof, is hereby prohibited. The article shall be inoperative unless it shall have been ratified as an amendment to the Constitution by conventions in the several States, as provided in the Constitution, within seven years from the date of the submission hereof to the States by the Congress.

\section{FREE COLLEGE}

$\mathrm{Al}$ Neuharth, the founder of USA Today, supports making tuition free in public colleges and universities (38). These are his reasons. Families spend an average of $\$ 64$ billion in tuition a year to send 13.9 million students to public colleges and universities. For the last 10 years, $\$ 1.1$ trillion has been spent on the wars in Iraq and Afghanistan, an average of more than $\$ 110$ billion annually. Sixty-four billion dollars annually for higher education and $\$ 110$ billion annually for wars! The two wars have also cost approximately 5700 military lives, and many of those killed in the wars were college-aged men and women. The war costs are paid for through present taxes but mostly debts piled up for future generations. The college costs are paid for by parents and/or long-time debts for graduating students. As Neuharth questions: "Can you think of any reason why anybody should not want to substitute higher education for our young men and women to ensure their future rather than military service and the futile nation-building efforts abroad?"

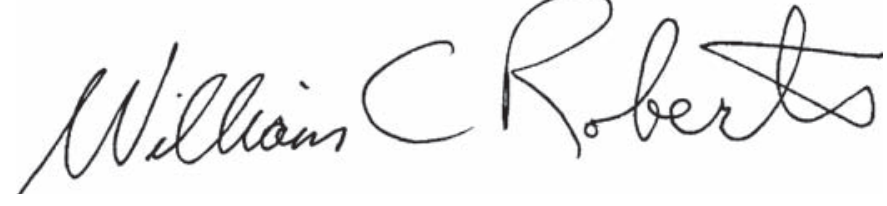

-William Clifford Roberts, MD

17 November 2010

1. Green LA. Cholesterol-lowering therapy for primary prevention: still much we don't know. Arch Intern Med 2010;170(12):1007-1008.

2. Ray KK, Seshasai SR, Erqou S, Sever P, Jukema JW, Ford I, Sattar N. Statins and all-cause mortality in high-risk primary prevention: a metaanalysis of 11 randomized controlled trials involving 65,229 participants. Arch Intern Med 2010;170(12):1024-1031.

3. de Lorgeril M, Salen P, Abramson J, Dodin S, Hamazaki T, Kostucki W, Okuyama H, Pavy B, Rabaeus M. Cholesterol lowering, cardiovascular diseases, and the rosuvastatin-JUPITER controversy: a critical reappraisal. Arch Intern Med 2010;170(12):1032-1036.

4. Roberts WC. Atherosclerotic risk factors-are there ten or is there only one? Am J Cardiol 1989;64(8):552-554.

5. Roberts WC. Atherosclerosis: its cause and its prevention. Am J Cardiol 2006;98(11):1550-1555.

6. Steinberg D. The Cholesterol Wars: The Skeptics vs. the Preponderance of Evidence. Amsterdam, the Netherlands: Elsevier, 2007 (227 pp.).
7. Truswell AS. Cholesterol and Beyond: The Research on Diet and Coronary Heart Disease, 1900-2000. Sydney, Australia: Springer, 2010 (227 pp.).

8. Keys A. Seven Countries: A Multivariate Analysis of Death and Coronary Heart Disease. Cambridge, MA: Harvard University Press, 1980 (381 pp.).

9. Verschuren WM, Jacobs DR, Bloemberg BP, Kromhout D, Menotti A, Aravanis C, Blackburn H, Buzina R, Dontas AS, Fidanza F, Karvonen MJ, Nedelijkovi S, Nissinen A, Toshima H. Serum total cholesterol and long-term coronary heart disease mortality in different cultures. Twenty-five-year follow-up of the Seven Countries study. JAMA 1995;274(2):131-136.

10. Kromhout D, Menotti A, Blackburn H, eds. The Seven Countries Study: A Scientific Adventure in Cardiovascular Disease Epidemiology. Bilthoven, the Netherlands: Marjan Nijssen-Kramer, 1993 (219 pp.).

11. Anitschkow NN. A history of experimentation on arterial atherosclerosis in animals. In Blumenthal HT, ed. Cowdry's Arteriosclerosis: A Survey of the Problem, 2nd ed. Springfield, IL: Charles C. Thomas, 1967:21-44.

12. Kannel WB, Dawber TR, Kagan A, Revotskie N, Stokes J 3rd. Factors of risk in the development of coronary heart disease—six year follow-up experience. The Framingham Study. Ann Intern Med 1961;55:33-50.

13. Kannel WB, Castelli WP, Gordon T. Cholesterol in the prediction of atherosclerotic disease. New perspectives based on the Framingham study. Ann Intern Med 1979;90(1):85-91.

14. Mautner SL, Sanchez JA, Rader DJ, Mautner GC, Ferrans VJ, Fredrickson DS, Brewer HB Jr, Roberts WC. The heart in Tangier disease. Severe coronary atherosclerosis with near absence of high-density lipoprotein cholesterol. Am J Clin Pathol 1992;98(2):191-198.

15. Libby P, Ridker PM, Maseri A. Inflammation and atherosclerosis. Circulation 2002;105(9):1135-1143.

16. Roberts WC. Qualitative and quantitative comparison of amounts of narrowing by atherosclerotic plaques in the major epicardial coronary arteries at necropsy in sudden coronary death, transmural acute myocardial infarction, transmural healed myocardial infarction and unstable angina pectoris. Am J Cardiol 1989;64(5):324-328.

17. Roberts WC, Turnage TA 2nd, Whiddon LL. Quantitative comparison of amounts of cross-sectional area narrowing in coronary endarterectomy specimens in patients having coronary artery bypass grafting to amounts of narrowing in the same artery in patients with fatal coronary artery disease studied at necropsy. Am J Cardiol 2007;99(5):588-592.

18. Sprecher DL, Schaefer EJ, Kent KM, Gregg RE, Zech LA, Hoeg JM, McManus B, Roberts WC, Brewer HB Jr. Cardiovascular features of homozygous familial hypercholesterolemia: analysis of 16 patients. $\mathrm{Am} \mathrm{J}$ Cardiol 1984;54(1):20-30.

19. Grundy SM, Cleeman JI, Merz CN, Brewer HB Jr, Clark LT, Hunninghake DB, Pasternak RC, Smith SC Jr, Stone NJ; National Heart, Lung, and Blood Institute; American College of Cardiology Foundation; American Heart Association. Implications of recent clinical trials for the National Cholesterol Education Program Adult Treatment Panel III guidelines. Circulation 2004;110(2):227-239.

20. Roberts WC. The underused miracle drugs: the statin drugs are to atherosclerosis what penicillin was to infectious disease. Am J Cardiol 1996;78(3):377-378.

21. Roberts WC. Shifting from decreasing risk to actually preventing and arresting atherosclerosis. Am J Cardiol 1999;83(5):816-817.

22. Cohen JD, Cziraky MJ, Cai Q, Wallace A, Wasser T, Crouse JR, Jacobson TA. 30-year trends in serum lipids among United States adults: results from the National Health and Nutrition Examination Surveys II, III, and 1999-2006. Am J Cardiol 2010;106(7):969-975.

23. Yeh RW, Sidney S, Chandra M, Sorel M, Selby JV, Go AS. Population trends in the incidence and outcomes of acute myocardial infarction. $N$ Engl J Med 2010;362(23):2155-2165.

24. Stone G. The Secrets of People Who Never Get Sick. New York: Workman Publishing, 2010 (212 pp.).

25. Stoller G. Traveling abroad's top risk: roads. USA Today, October 21, 2010. 
26. Stoller G. U.N. program urges global road safety. U.S. traveler dies on foreign road every 36 hours on average. USA Today, October 21, 2010 .

27. Jeffrey TP. It's official: Obama has now borrowed $\$ 3$ trillion. CSN News. Available at http://www.cnsnews.com/news/article/it-s-official-obamahas-now-borrowed-3-t; accessed October 18, 2010.

28. Siegel M. Why ObamaCare will clog the system. USA Today, October 19, 2010.

29. Appiah KA. Accepted now, unforgivable later. Dallas Morning News, October 17, 2010.

30. Milken M. Toward a new American century. Wall Street Journal, October 7, 2010 .

31. 27 floors just right for family of five. Dallas Morning News, October 30, 2010 .
32. Henrietta Lacks. In Wikipedia. Available at http://en.wikipedia.org/wiki/ Henrietta_Lacks; accessed November 17, 2010.

33. Singer N. Botox ok'd as migraine treatment. Dallas Morning News, October 17, 2010.

34. Ritter K, Rising M. In vitro pioneer wins Nobel in medicine. Dallas Morning News, October 5, 2010.

35. Dougherty C. New vow: I don't take thee. Wall Street Journal, September 29, 2010.

36. Associated Press. Grandparents raising kids: rising numbers, rising stress. Dallas Morning News, September 11, 2010.

37. Okrent D. Last Call: The Rise and Fall of Prohibition. New York: Scribner, 2010 (468 pp).

38. Neuharth A. Should free college be a part of education? USA Today, November 12, 2010. 